\title{
Community engagement and waste management policy: A comparative analysis
}

\author{
Agus Brotosusilo ${ }^{1 *}$ and Siti Hilya Nabila² \\ ${ }^{1}$ Faculty of Law, Universitas Indonesia, Depok, West Java 16424, Indonesia \\ ${ }^{2}$ Faculty of Social and Political Science, Universitas Indonesia, Depok, West Java 16424, Indonesia
}

\begin{abstract}
Municipal waste management has become a significant problem in many urban areas where solutions are complex and conflicting to form. One of the most important actors that can control waste management in a country is the government. Then the most important tool for setting standards in maintaining waste management is the public policy. Therefore, this paper will review and evaluate public policies that regulate solid waste management in China, Japan, and Malaysia, using secondary data. The three countries were chosen because their cases represented various significant and different factors that have often been an obstacle to waste management. The three case studies discuss community behavior analysis, policy mistranslation, and the lack of waste management infrastructure. The main obstacles of the waste management policy are to control people's behavior, lack of garbage infrastructure, waste pickers are not organized, and lack of progress in waste management and recycling technology. The waste management policy needs to focus on increasing residents' awareness to recycle and expand the producer's responsibility to increase community engagement and boost successful waste management in a region or country.
\end{abstract}

\section{Introduction}

The increase in the population has an impact on the increase in existing urban waste. However, management of waste disposal is often a challenge in a community, especially in urban communities. Since 2010, there have been many public policies in various countries, trying to regulate waste management. Policies created include creating a campaign about reducing inorganic waste in setting a monthly bill for residents to support waste management operations [1]. However, the current policies to address waste are targeted to be improved in the coming years [2]. That happened because there are still many problems that inhibit that policy's effectiveness, which is difficult to achieve. After all, the effectiveness of policies is also determined by matters such as the community's commitment to participate in attaining the policy's target and the government's ability to control people's behavior [3]. In addition, in achieving proper waste management, the government must also optimize waste management technology [4]. In this paper, we will describe the cases that occur in various countries, starting from general waste to solid waste management and recycling systems.

\footnotetext{
*Corresponding author: broto.susilo@ui.ac.id
} 
There are two types of wastes, solid waste, and organic waste. In environmental studies, solid waste management has also become a concern lately due to the more serious difficulty of managing solid waste than organic waste [5]. With the increase in the economic, population, and tourism sectors, solid waste management is a major challenge for a country [6]. Municipal waste management has become a significant problem in many urban areas where solutions are complex and conflicting to form. The obstruction of the optimization of adequate municipal waste management is caused by various factors, ranging from low public participation, government policies mistranslation, low priority of society from low socioeconomic status circles to environmental cleanliness, and loss of public trust intransparent government policies. The issue of waste management is a critical problem to be studied because the failure of waste management can lead to the emergence of various significant public welfare problems. The simplest example of a possible welfare problem is the emergence of a dangerous disease virus from an environmentally unsafe waste collection sites. One of the most important actors that can control waste management in a country is the government. Then the most important tool for setting standards in maintaining waste management is the public policy. Structural problems, such as national-level policies and regulations at the local level, are the main factors that can support the effectiveness of waste management. The main obstacle which can occur is when the principle of protecting the environment, for instance: Zero Waste (Refuse, Reuse, Reduce), has been integrated into national policy, but the same principle is not integrated into regional regulations. Alternatively, integrated but not appropriately implemented, and the central government also has difficulty controlling this problem [7]. However, the policy has many obstacles that ultimately inhibit the realization of the policy's main objectives. Because of that, this paper tried to evaluated and review the waste management in China, Malaysia, and Japan to provide a better recommendation about waste management policy.

Moreover, the successful implementation of a system has to do with community involvement [8]. Community awareness of the environment and waste management will help improve waste management [8]. Waste management with community contribution and volunteerism is the social capital that drives the success of the waste management process [9]. That is because the closeness and trust between individuals in society have a more significant influence than the resulting economic value [9]. The community is the garbage producer itself, so its participation is influenced by awareness of waste management by the community itself $[8,9]$. Community participation is essential to identify waste management problems, and all layers need to have a proper understanding of waste management issues. Community empowerment encourages individuals to be involved in increasing community involvement in environmental, social activities, including waste management [10]. Therefore, this study will evaluate community behavior and participation in relation to waste collection regulations from China, Japan, and Malaysia.

\section{Method}

This study uses a qualitative method in which this paper will collect various literature studies that explain the national strategies China, Malaysia, and Japan countries to deal with municipal waste management. The three countries were chosen because their cases represented various significant and different factors that have often been an obstacle to waste managementManagement. The three case studies discuss community behavior analysis, policy mistranslation, and the lack of waste management infrastructure provided by the government.

Qualitative methods are research methods that emphasize the importance of observing research subjects or case studies. That can be conducted by collecting, mapping, and 
interpreting literature studies related to certain cases. This paper used a secondary document for Table 1 and Table 2 results generated from the previous journal. After the literature study is collected, this paper will also dissect and map each literature's arguments. The results of the literature observations in this paper will draw a conclusion regarding the main obstacles in municipal waste management in several Asian countries.

\section{Results and discussion}

Before dissecting one by one how municipal waste management is regulated in several Asian countries, several tables will show the position or performance of countries - countries that are the subjects of this paper-in dealing with solid waste management. China, Japan, and Malaysia, whose national strategies for MSW will be analyzed in this paper, are expected to experience an increase in the waste generation rate in 2025. That shows from Table 1, which is generated from literature, that each capita in China and Malaysia will increase waste generation around $0,1 \mathrm{~kg} /$ day from 2009 to 2025 . At the same time, Japan has increased waste generation around 0,2 kg/day from 2009 to 2025. That shows the MSW management becomes a significant issue that must be prioritized in the national agenda. Since, if calculated in total from China only, which is have more than 1 billion people, It means there is more than 1 million $\mathrm{kg} /$ day waste will be generated in 2025 .

Table 1. Increase in estimated waste generation rate in 2025 indicates the urgency of municipal solid waste (MSW) management [11].

\begin{tabular}{|c|c|c|}
\hline Country & $\begin{array}{c}\text { Waste Generation Rate } \\
\text { (Kg/Cap/Day) in 2009 }\end{array}$ & $\begin{array}{c}\text { Prediction of Waste Generation } \\
\text { (Kg/Cap/Day) in 2025 }\end{array}$ \\
\hline China & 0,8 & 0,9 \\
\hline Japan & 1,1 & 1,3 \\
\hline Malaysia & 1,3 & 1,4 \\
\hline
\end{tabular}

Table 2. Composition type of MSW (\%) in China, Japan, and Malaysia [11].

\begin{tabular}{|l|c|c|c|c|c|c|}
\hline \multirow{3}{*}{ Country } & \multicolumn{7}{|c|}{ Type of Municipal Solid Waste Composition (\%) } \\
\cline { 2 - 7 } & $\begin{array}{c}\text { Food waste } \\
\text { (organic) }\end{array}$ & Paper & Plastic & Metal & Glass & Others \\
\hline China & 49 & 16 & 16 & 2 & 1 & 16 \\
\hline Japan & 15 & 50 & 20 & 2 & 1 & 4 \\
\hline Malaysia & 47 & 15 & 14 & 4 & 3 & 17 \\
\hline
\end{tabular}

Table 2, which is generated from the same literature, shows that in China and Malaysia, organic/food waste is dominant than the other type composition, which is $46 \%$ from total waste generated in China and 47\% from total waste in Malaysia. From the type of MSW waste generated, it can conclude that in the term of household waste in both countries not yet properly managed. In Malaysia, due to the visual disturbances and pollution affected by SWM, the community's willingness to pay for the waste collection fee is low. The government has deprived society's reliance regarding SWM. Therefore, two problems in SWM are high public demand for improving the SWM quality and low WTP (Willing to Pay) rate. Pek and Jamal argue that this type of obstacles can be addressed if the government considers increasing society's willingness to pay (WTP) by creating waste disposal improvements which are impactful and beneficial to the society [12]. Slightly different from Pek and Jamal, Liu et al. discussed household waste management in rural areas. Disposal of household waste in rural areas is a significant problem for developing countries, threatening the national economy. If not handled properly, poor waste management also causes flooding, as happened in China, where solid waste management has become a major discussion among 
stakeholders [13]. In China, only 36\% of all rural areas have waste collection and disposal services for their communities. To be more specific, only $81 \%$ of the villagers dispose of household waste at the designated locations. In sample villages, rural residents tend to dispose of household waste properly at garbage dumping sites if the waste services are provided. That signifies that infrastructure development is very necessary to maintain the environment cleanliness [14]. Two important problems should properly manage: the availability of organized garbage dumping sites greatly influences rural people's behavior, and rural residents tend to be more willing to dispose of household waste if the garbage dumping site is close to their homes. In conclusion, structural factors are very influential in maintaining environmental cleanliness.

In China, the policy regulating waste is still not paying enough attention to household waste disposal infrastructure, especially in rural areas. Supposedly, the compliance of waste disposal infrastructure is built evenly so that all geographical areas have garbage dumping sites that are not too far from people's homes [15]. There are many waste pickers, but their existence is less noticed by society and government. Chen et al. found that in Nanjing, China, there are $70-80 \%$ MSP materials collected by waste pickers informally [16]. That material that is collected has the same value, with around 82 million USD. The work of the waste pickers in Nanjing has succeeded in helping the private sector save up to 22 million USD during the MSW disposal process each year. However, unfortunately, waste pickers only receive around an average of $8 \%$ profit from the process. If the government more gives value to them, that can help the waste collectors have a more equitable benefit, and it can provide a better and successful waste management practice [15].

Meanwhile, from Table 2, In Japan, the largest composition of waste is paper waste, which is around $50 \%$ of the total waste generated in that country. It means that in there, the household solid waste has been managed better than China and Malaysia. According to Zheng et al., there are four strategies to implement a door-to-door recycling scheme for household solid waste in Nagoya, Japan. These strategies are; 1) increase the awareness of residents to recycle; 2) garbage service providers have insurance while operating recycling system mechanism; 3) expanding the responsibility of the producer; 4) develop in-depth research related to proper treatment for organizing door-to-door recycling schemes [16]. Nevertheless, these strategies cannot directly make recycling done by the community. The government must also build public awareness about recycling itself [17-19].

However, the main problem with door-to-door recycling scheme management in most countries is the lack of government attention in creating environmentally-friendly policies. That can provide or empower private parties to provide facilities and technology to properly sort waste material - technology that can ease the recycling process and reduce the risk caused by recycling [16]. Because of that, community engagement becomes important to manage household waste to boost the community to be more organized to dumping. They are waste and more willing to dispose of household waste in the dumping site. Community engagement can also increase the willingness to pay (WTP) of society since the behavior influences are significant factors. Since waste management with community contribution and volunteerism is the social capital that drives the waste management process's success. Moreover, closeness and trust between individuals in society have a more significant influence than the resulting economic value [8]. Other than that, for better waste management, the waste management policy needs to focus on increasing residents' awareness to recycle [20] and expand the producer's responsibility. To provide better waste management, which is prevention action to the increase of waste generated in 2025 .

\section{Conclusion}


The main obstacles of the waste management policy are; 1) difficulty in controlling people's behavior such as the difficulty of increasing willingness-to-pay (WTP) among residents and recycling habit; 2) garbage sites infrastructure which is not available in many rural areas; 3 ) waste pickers are not organized by the government; 4) lack of progress in waste management and recycling technology which does not endanger the environment. Therefore the community engagement is important to maximize the success of waste management policy. Moreover, the waste management policy needs to focus on increasing residents' awareness to recycle and expand the producer's responsibility to the community engagement can be increase and then boost the successful waste management in region or country. This paper results can be given another perspective to make waste management successful, but it also needs to see each region's condition.

\section{Acknowledgements}

This research was funded by the Higher Education Leading Basic Research Program (PDUPT) 2020 of the Ministry of Research and Technolog/National Research and Innovation Agency (Penelitian Dasar Unggulan Perguruan Tinggi (PDUPT) Kementerian Riset dan Teknologi/Badan Riset dan Inovasi Nasional/KEMENRISTEK/BRIN-Universitas Indonesia with contract numbers 8/E1/KP.PTNBH/2020 and 255/PKS/R/UI/2020

\section{References}

1. T.D. Nielsen, K. Holmberg, J. Stripple, Waste Manag. 87, 428-440 (2019)

2. L. Breitenmoser, T. Gross, R. Huesch, J. Rau, H. Dhar, S. Kumar, C. Hugi, T. Wintgens, J. Environ. Manage. 236, 396-412 (2019)

3. C. Wan, G.Q. Shen, A. Yu, Resour. Conserv. Recycl. 83, 141-151 (2014)

4. K.D. Sharma, S. Jain, J. Environ. Eng. (United States) 145 (2019)

5. S. Lalitha, R. Fernando, Waste Manag. 84, 194-203 (2019)

6. G. Meylan, A. Lai, J. Hensley, M. Stauffacher, P. Krütli, Environ. Sci. Pollut. Res. 25, 35791-35804 (2018)

7. M. Nizar, E. Munir, Irvan, V. Waller, IOP Conf. Ser. Earth Environ. Sci. 216 (2018)

8. I. Yunita, J. Community Engagem. 01, 24-29 (2019)

9. W.H. Prasetiyo, K.R. Kamarudin, J.A. Dewantara, J. Hum. Behav. Soc. Environ. 29, 9971014 (2019)

10. A. Brotosusilo, S.H. Nabila, H.A. Negoro, D. Utari, Glob. J. Environ. Sci. Manag. 6, 341354 (2020)

11. P. Agamuthu, S.H. Fauziah, C.U. Emenike, Waste Management in Asia : the Proceedings of 3rd International Conference on Ecotoxicology and Environmental Sciences (Panaji) (2011)

12. C.K. Pek, O. Jamal, J. Environ. Manage. 92, 2993-3001 (2011)

13. W. Liu, W. Chen, Q. Feng, R.C. Deo, Water Sci. Technol. Water Supply 19, 115-127 (2019)

14. F. Wang, Z. Cheng, A. Reisner, Y. Liu, J. Clean. Prod. 202 293-298 (2018)

15. F. Chen, Z. Luo, Y. Yang, G.J. Liu, J. Ma, Waste Manag. Res. 36, 767-778 (2018)

16. P. Zheng, K. Zhang, S. Zhang, R. Wang, H. Wang, The door-to-door recycling scheme of household solid wastes in urban areas: a case study from Nagoya, Japan (Elsevier Ltd, 2017)

17. L.E. Whitmarsh, P. Haggar, M. Thomas, Front. Psychol. 9, 1-13 (2018)

18. A.D.N. Gunarathne, T.P.Y.C. Tennakoon, J.R. Weragoda, J. Mater. Cycles Waste Manag. 21, 181-190 (2019)

19. V. Ruliana, R.W. Soemantojo, D. Asteria, ASEAN Journal of Community Engagement, 


\section{3, 1 (2019)}

20. H.P. Johannes, Journal of Environmental Science and Sustainable Devevelopment 1, 1 (2018) 